\title{
Interrelationship Among Basel Capital Regulation, Risk, and Efficiency in Pakistani Commercial Banks
}

\author{
Adnan Bashir ${ }^{1}$, Arshad Hassan ${ }^{2}$
}

\begin{abstract}
This study examines the interrelationship among Basel capital regulations, risk, and efficiency of Pakistani commercial banks from 1997-2015. It uses the Generalized Method of Moments (GMM) technique from beginning of capital regulation in 1997 to 2015. We find that bank capital regulation reduces the bank risk. As far as the impact of capital regulation on bank efficiency is concerned, it reduces the bank efficiency. Our results also indicate that the effect of capital regulation on bank risk and cost efficiency is different for each of the Basel accords. Moreover, Basel II was more successful than Basel I in reducing the risk taken by banks, while its impact on the cost efficiency of banks was negligible.
\end{abstract}

Key words: bank-risk taking, bank efficiency, capital regulation

JEL Classification: E5, E52, G21

\section{Introduction}

Banks play the role of life blood for a country's economy. Efficient banking gives rise to financial stability which guarantees higher-quality services at low costs to businesses and common man. If the banking system of a country is functioning well, it will give rise to the long run growth of that country. According to Levine and Zervos (1998), banks serve as lubricating oil for the economy and their failure leads to the failure of whole society.

Due to the special nature (vital role in the payments system, allotment of financial resources, highly leveraged due to deposits etc.) of banks in the economy a high degree of regulation and supervision is required. According to the Santos (2001), the banking sector has great deal of regulations to contend with the whole world. Laeven and Valencia (2013) are of the view that the importance of financial supervision regulation grew with the increasing number of banking crises since 1970s. Until the 1970s

1 Capital University of Science $\mathcal{E}$ Technology. Email: iadnanb@yahoo.com

2 Associate Professor, Capital University of Science and Technology, Islamabad. Email: aarshad. hasan@gmail.com

ARTICLE HISTORY
\begin{tabular}{lll}
8 Nov, 2016 Submission Received & 23 Nov, 2016 & First Review \\
\hline 2 Feb, 2017 Revised Version Received & 20 Feb, 2017 & Second Review \\
\hline 10 Mar, 2017 Revised Version Received & 1 Apr, 2017 & Accepted
\end{tabular}


there was no international consistency among banks operated in different countries. Individual countries were responsible for the regulation of banks operated within their borders. According to the Mourlon-Druol (2015), the failure of Herstatt Bank in Germany in 1974 and Franklin National Bank of New York in 1974 provided the stimuli for stronger bank regulations.

These bank failures forced the G-10 nations to formulate the Basel Committee on Bank Supervision (BCBS) in 1974. One of the most important developments in this regard was the formation of Basel Committee on Banking Supervision (BCBS) in 1974 to recommend rules for working of banking sector. The core task of the committee was to recommend rules for working of banking sector. So that, in future, collapse of globally active banks can be avoided. The committee developed consensus on its first accord known as Basel I in 1988. This accord was amended and after overcoming the shortcomings in Basel I, second accord known as Basel II was finalized. It incorporated operational risk and market risk along with credit risk in its risk based calculations. Moreover, it also introduced two new pillars: Market Discipline and Supervisory review. Both Basel I and II forced the banks to hold a least level of total capital to risk-weighted assets equal to $8 \%$. Since 2010, a third accord namely Basel III has come into play. This has increased capital regulation from $8 \%$ to $10 \%$ along with taking some other initiatives.

Pakistan banking regulator, State Bank of Pakistan has started implementing Basel Accord I recommendation from Dec 1997, Basel II in 2008 and Basel III from 2014. The purpose of this study is to investigate the impact of implementation of capital regulation of Basel accord on efficiency and risk taking of Pakistani banks. This paper makes its contribution in several ways. First, there is abundance of literature available on Europe and U.S. (de Guevara, Maudos \& Pérez, 2007; Carbó, Humphrey, Maudos \& Molyneux, 2009), however there is not much literature available that examines the relationship of Basel Accord with efficiency and risk taking of Asian countries and Pakistan is no exception to this. This is the one of few studies which examines the empirical relationship between efficiency, risk and capital in Pakistani banking sector only. Second, this study includes the banking data from 1998 to 2015; this time period includes the latest round of Basel banking reform in Pakistan i.e. Basel III. Finally, with regards to the econometric modeling framework, we use the GMM. Though this technique is not new, however in Pakistani banking regulation research, it is not vastly used. We attempt to fill the gaps in literature by providing empirical evidences solely on the impact of Basel capital regulations on Pakistani banking sector. The findings of this study are beneficial for State Bank of Pakistan (SBP) and banks to assess the consequences of implementation of Basel regulations in terms of risk reduction and efficiency enhancement. 


\section{Literature Review}

The theoretical foundation of current study inhales from the agency theory and financial intermediation theory. Though work of Jensen and Meckling (1976) is considered to be the pioneer, however contribution of Fama (1980) is notable in this regard. He states that governance mechanism is necessary to bring into line the interests of principals (depositor) and agents (bankers). The financial intermediation theory finds its roots in the theory of informational asymmetry and the agency theory. Lack of trust between borrower and lender encourages the role of financial intermediary due to its ability to optimal allocation of resources as advocated by Levine (1997), reduces transaction cost by means of economies of scale (Scholes, Benston, \& Smith Jr., 1976) and its role as "delegated monitors" as argued by Diamond (1984).

Literature presents mixed argument on effect of regulatory capital on banking performance. Despite a lot of empirical research there is no consensus on the relationship between the two. One school of thought advocates the negative impact of strict capital requirement on bank profitability and efficiency (Repullo \& Suarez, 2008). However, another school of researchers are of the view that severe capital requirement has a positive impact on cost efficiency (Pasiouras, Tanna, \& Zopounidis, 2009; Barth, Caprio, \& Levine, 2004)

Pioneer work on capital structure and risk was done by Pettway (1976). He explored the relationship on American banks and their holding firms during 1971 to 1974. By applying ordinary least square method, he found a favorable relationship between equity-to-total-assets and risk.

Shrieves and Dahl (1992) investigated the relationship of risk and capital on 1,800 US bank holding companies. They used simultaneous equation model to calculate the result of changes in risk on changes in capital and vice versa. They reported a positive relationship.

In a seminal study Berger and De Young (1997) explored the inter-temporal relationships among problem loans and cost efficiency of US banks. They proposed hypothesis 'bad luck,' 'bad management,' 'skimping' behavior for the risk and efficiency. By employing Granger-causality techniques over US bank data of 1985 to 1994 they reported in favor of bi-directional relationship loan quality and cost efficiency. Their data supported the bad luck hypothesis. According to this hypothesis increase in nonperforming loans to Granger-cause decrease in measured cost efficiency. They suggested that high values of problem loans caused banks to raise either expenditure on monitoring or dispose of these loans, and thus banks became more attentive in looking after the portion of their on hand loan portfolio. 
Kwan and Eisenbeis (1997) tried to analyze the relationship among risk, capitalization and measured inefficiencies. They empirically tested the association on 254 large bank holding companies during the period 1986 through 1991. They used simultaneous equation framework and concluded that these three variables were simultaneously determined. They reported a negative relationship between risk and efficiency.

Jacques and Nigro (1997) checked the link between risk and capital for over two thousand and five hundred American banks. By applying 3 stages least squares method, they observed an inverse connection between risk and capital.

Das and Ghosh (2004) studied the interrelationships among capital, risk-taking and operating efficiency of the Indian banking system. They reported that efficiency had a positive effect on risk and capitalization.

Altunbas, Carbo, Gardener, and Molyneux (2007) used a static simultaneous equation framework to explore the relationship between capital, risk and efficiency for a sample of European banks over the period 1992-2000. They reported a positive relationship between risk and level of capital.

Fiordelisi, Marques-Ibanez, and Molyneux (2011) checked the inter-temporal relationship between bank efficiency, capital and risk in European banking industry. They used Granger-causality techniques for the period 1995-2007. They employed Stochastic Frontier Approach (SFA) to measure the efficiency and capital to asset ratio as a proxy for capital. They observed a negative, although little, connection of capital and risk.

Lee and Hsieh (2013) analyzed the impact of capital on risk in 42 Asian countries. They applied the Generalized Method of Moments technique over the period of 1994 to 2008. They portrayed a mix picture of the two variables. Their results showed inverse relationship between capital and risk for banks in Far East and Central Asia in the sample, while data of high-income countries had the positive impact of capital on risk.

Tan and Floros (2013) assessed the relationship between the bank risk and capital for a sample of Chinese commercial banks. They employed different proxies for risk (volatility of ROE, Z score etc.) and book value of capital to total assets for capital. They found a negative relationship between risk and capitalization.

Haq, Faff, Seth, and Mohanty (2014) explored the effect of capital on risk for 218 listed banks across 15 Asia-Pacific countries. They performed their research on 15 years' time span (1996-2010) using Generalized Method of Moments technique. By using different proxies of risk i.e. systematic risk and $\mathrm{Z}$ score and tier 1 for capital, 
they observed a positive association of bank capital with bank risk. Therefore, they took the line of regulatory hypothesis.

Miah and Sharmeen (2015) looked at the relationship between efficiency, capital and risk-taking behavior of Bangladeshi banks. The sample of their study was of Islamic and conventional banks of Bangladesh for the time span of (2001-2011). They reported that all the variables: capital, risk and efficiency are simultaneously determined. Their researches supported the various hypotheses between capital, risk and efficiency.

\subsection{Hypotheses of the Study}

Regulatory hypothesis is presented by Pettway (1976). Regulatory hypothesis advocates the positive connection of capital and risk. This hypothesis states that regulators persuade banks to raise their capital substantially with the level of risk they acquire to counter the risk of default.

$\mathrm{H}_{1 \mathrm{~A}:}$ Bank risk increases with bank capital.

However, another school of researchers led by Kim and Santomero (1988) questioned the notion of forcing banks to maintain levels of required capital. They supported the moral hazard hypothesis, that banks have advantages to make use of presented flat deposit insurance schemes, which reflect a negative relationship among capital and risk.

$\mathrm{H}_{1 \mathrm{~B}}$ : Bank risk decreases with bank capital.

Under the skimping hypothesis banks, there is positive relationship between risk and efficiency. Banks can choose to devote fewer resources to monitor loans and non-performing loans remain unaffected in short term.

$\mathrm{H}_{2 \mathrm{~A}}$ : Bank risk increases with bank efficiency.

According to Berger and De Young (1997) proposed Bad management, Bad luck and skimping hypothesis. Bad management hypothesis proposes an inverse relationship between risk and cost efficiency. According to this hypothesis due to poor management, cost efficiency of bank is decreased. As a result of this bad management, less efficient banks will take more risk to compensate the effect of inefficiency.

Bad luck hypothesis also advocates the negative relationship between risk and cost efficiency. However, this hypothesis states that instead of bad management, external events caused nonperforming loans to rise. This increase in risk gives rise to additional costs and as a result cost efficiency of banks decreased. 
$\mathrm{H}_{2 \mathrm{~B}}$ : Bank risk decreases with bank efficiency.

With regards to impact of capital on efficiency shareholders-debtholders hypothesis states that due to conflicts of interest between shareholders and debt holders', there will be less debt financing. This will lead to low agency cost i.e. high efficiency and high capital ratios.

\section{$\mathrm{H}_{3 \mathrm{~A}}$ : Bank capital increases with bank efficiency.}

However, shareholders-managers hypothesis states that capital has a negative impact on efficiency. Due to moral hazardous behavior of managers, agency cost increases and free cash at the disposal of managers i.e. equity-to-assets ratio decreases. So, high capital ratio has a negative impact on efficiency and vice versa.

\section{$\mathrm{H}_{3 \mathrm{~B}}$ : Bank capital decreases with bank efficiency.}

\section{Methodology}

The effect of Basel capital regulations on the bank risk and bank efficiency is checked by using the Generalized Method of Moments (GMM). GMM approach has been adopted due to the likelihood of endogeneity issues of bank capital, bank risk and bank efficiency, individual time-invariant fixed effects heterogeneity, autocorrelation and the fact that the cross-sections are greater than the time periods for the available data. According to Stock and Watson (2011) OLS methods will produce inconsistent and biased estimates when the variables are jointly determined. Weak strength of available Instrumental variables (IV) also make the GMM technique a more appropriate and robust technique than seemingly unrelated regression, panel-corrected standard error estimates and instrumental variable and the two-stage least square. Lee and Hsieh (2013), Haq et al. (2014) have also used System Generalized Method of Moments (GMM) in their respective studies. According to the Roodman (2006) rule of thumb in estimation of GMM is the number of units (banks) must be greater than the instruments being used. To overcome the problem of too many instruments, collapse option as suggested by Roodman (2009) is used. The validity of the instruments is checked by the Hansen (and difference-in-Hansen) tests of over-identifying restrictions.

\subsection{Data and Sample}

Sample of this study consists of all listed commercial banks from 1997 to 2015 in Pakistan. The data was gathered from Bank scope data base. Individual banks' annual financial statements were used to verify and find the missing data. 


\subsection{Empirical Model}

With respect to proxies being used, previous studies have used different measures of bank capital (BC), bank risk (BR) and bank efficiency (BE). So different accounting based proxies of these variables will be used.

The following equations are used in the study.

$$
\begin{aligned}
& \mathrm{NPLGL}_{\mathrm{it}}=\alpha_{0}+\beta_{1} \mathrm{TCTR}_{\mathrm{it}}+\beta_{2} \mathrm{CIR}_{\mathrm{it}}+\beta_{3} \mathrm{NLTA}_{\mathrm{it}}+\beta_{4} \mathrm{SIZE}_{\mathrm{it}}+\beta_{5} \mathrm{INF}+\varepsilon \mathrm{i}(1) \\
& \mathrm{CIR}_{\mathrm{it}}=\alpha_{0}+\beta_{1} \mathrm{TCTR}_{\mathrm{it}}+\beta_{2} \mathrm{NPLGL}_{\mathrm{it}}+\beta_{3} \mathrm{NIM}_{\mathrm{it}}+\beta_{4} \mathrm{SIZE}_{\mathrm{it}}+\beta_{5} \mathrm{INF}+\varepsilon \mathrm{i}(2) \\
& +\varepsilon \mathrm{i} \\
& \text { TCTR }_{\text {it }}=\alpha_{0}+\beta_{1} \mathrm{NPLGL}_{\mathrm{it}}+\beta_{2} \mathrm{CIR}_{\mathrm{it}}+\beta_{3} \mathrm{LADSTF}+\beta 4 \mathrm{ROAA}_{\mathrm{it}}+\beta_{5} \mathrm{SIZE}_{\mathrm{it}}+\beta_{6} \mathrm{INF}
\end{aligned}
$$

To measure bank capital, total capital to total risk weighted assets (TCTR) is used. A high value of TCTR depicts that bank has more capital while small value of TCTR is signal of low capital. For bank risk, non-performing loans to gross loans (NPLGL) represents credit risk. For the measurement of efficiency, we are using cost to income (CIR) as proxy for cost efficiency. A low value of CIR suggests cost efficiency and high values indicates cost inefficiency. Moreover, in order to make equation identified, we have used (NLTA) net loans to total assets, (NIM) net interest margin, (LADSTF) liquid asset to deposit and short-term funding, (ROAA) return on average asset respectively. Previous studies have used different control variables in their work and we have used size as logarithm of total assets of bank and inflation in our study following the work of Tan and Floros (2013).

\section{Analysis and Results}

This section is organized in three parts. The first part of this section describes descriptive statistics of the dependent and independent variables. In the second section, we will check different assumptions of the data. In the third and last part we report the results of the link between bank risk, bank efficiency and bank capital using GMM with discussion.

\subsection{Descriptive Statistics}

In this section, descriptive statistics are provided of all the variables for all banks in the sample. Descriptive statistics are presented in Table 1. The proxy of the variable bank risk is NPGL and its mean value shows that all the banks in the sample take $12.74 \%$ risk on average.

While the minimum and maximum value of NPLGL depicts that banks take 
Table 1: Descriptive Statistics for Banks in the Years 1997 to 2015*

\begin{tabular}{|c|c|c|c|c|c|c|c|c|c|}
\hline & NPLGL & CIR & TCTR & NLTA & $\begin{array}{c}\text { LAD- } \\
\text { STF }\end{array}$ & ROAA & NIM & SIZE & INF \\
\hline Mean & 12.74 & 74.83 & 16.07 & 45.92 & 17.96 & 0.52 & 3.91 & 11.45 & 8.75 \\
\hline S.D & 10.22 & 56.04 & 10.22 & 11.30 & 13.28 & 2.00 & 1.88 & 1.44 & 4.85 \\
\hline Min & 0.2 & 0 & 0.08 & 10.05 & 0.06 & -12.29 & -1.45 & 7.85 & 2.54 \\
\hline Max & 78.76 & 494.7 & 65.43 & 70.94 & 77.54 & 5.11 & 9.3 & 14.61 & 20.29 \\
\hline
\end{tabular}

${ }^{*}$ Values rounded off to two decimal places

risk from low of $2 \%$ to high of $78.76 \%$. The variable bank efficiency is peroxided by CIR and its mean value shows that all the banks in the sample have average $78.73 \%$ efficiency. CIR minimum and maximum value displays banks cost efficiency ranges from $0 \%$ to $494.7 \%$. The proxy of the variable bank capital is TCTR and it has average value of 16.07 which shows that all the banks in the sample have averagely $16 \%$ capital. While the maximum value of TCTR is 65.43 and minimum value is .08 which shows the bank capital ranges from minimum of $8 \%$ to maximum of $65.43 \%$. Net Loans to Total Asset (NLTA) have average value of 45.92. This shows that NLTA average and middle values of $46 \%$. While it's maximum and minimum value ranges from low of $10.05 \%$ to high of $71 \%$. LADSTF has values from a low of $6 \%$ to high of $78 \%$ with average value being $18 \%$.Return on Average Asset (ROAA) has mean value of $52 \%$ and its value ranges from high of $5 \%$ to low of $-12 \%$. With respect to bank specific variable size has been used and its log has been taken and it has mean value of 11.45 while maximum of 14.61 and minimum of 7.85 . Similarly the macroeconomic control variables inflation is also reported in table 1 with its values varies from high of $20.29 \%$ to a low of $2.54 \%$.

\subsection{Testing for Multicollinearity}

The multicollinearity is verified by the Pearson correlation and the variance inflation factor (VIF). The correlation coefficients of independent variables for panel data (1997-2005) are illustrated in Table 3

The Pearson correlation is used to determine the association between independent and dependent variables. According to Gujarati (2009) correlation coefficient value of over 0.8 or 0.9 would create major issue. As none of our value reaches that point so in our case multicollinearity is unlikely to be a problem. This research also uses the variance inflation factor (VIF) to check multicollinearity. If VIF values for independent variables are higher than 10 or tolerance is not far from 0.10 , this indicates the existence of multicollinearity. Table 4 reports the VIF values for equation 1,2 , and 3 , respectively. 
Table 3: Correlation Matrix*

\begin{tabular}{|c|c|c|c|c|c|c|c|c|c|}
\hline & NPLA & CIR & TCTR & NLTA & LADST & NIM & ROAA & SIZE & INF \\
\hline NPLA & 1.00 & & & & & & & & \\
\hline CIR & 0.4206 & 1.00 & & & & & & & \\
\hline TCTR & 0.0215 & 0.0565 & 1.00 & & & & & & \\
\hline NLTA & -0.2935 & -0.0375 & -0.4241 & 1.00 & & & & & \\
\hline $\begin{array}{c}\text { LAD- } \\
\text { STF }\end{array}$ & 0.0012 & 0.0138 & 0.3615 & -0.1996 & 1.00 & & & & \\
\hline NIM & -0.343 & -0.3356 & 0.1898 & -0.0570 & -0.0090 & 1.00 & & & \\
\hline ROAA & -0.4273 & -0.6248 & -0.0668 & 0.0506 & -0.1166 & 0.4291 & 1.00 & & \\
\hline SIZE & -0.0578 & -0.2191 & -0.3716 & 0.0709 & -0.4581 & 0.3670 & 0.3133 & 1.00 & \\
\hline INF & -0.0348 & 0.1371 & 0.1087 & 0.2247 & 0.0222 & 0.2852 & -0.1761 & 0.0931 & 1.00 \\
\hline
\end{tabular}

*Values rounded off to four decimal places

Table 4: Variance Inflation Factor

\begin{tabular}{|c|c|c|c|c|c|}
\hline \multicolumn{2}{|c|}{ Risk Equation } & \multicolumn{2}{c|}{ Efficiency Equation } & \multicolumn{2}{c|}{ Capital Equation } \\
\hline Variable & VIF & Variable & VIF & Variable & VIF \\
\hline TCTR & 1.56 & NPLGL & 1.17 & NPLGL & 1.33 \\
\hline CIR & 1.09 & TCTR & 1.39 & CIR & 1.76 \\
\hline NLTA & 1.39 & NIM & 1.66 & LADSTF & 1.29 \\
\hline SIZE & 1.30 & SIZE & 1.54 & ROAA & 1.91 \\
\hline INF & 1.20 & INF & 1.10 & SIZE & 1.46 \\
\hline & & & & INF & 1.09 \\
\hline
\end{tabular}

As evident from the table, all values of VIF are less than 10. Therefore, multicollinearity is not an issue in our models.

\subsection{Test for Endogeneity}

Although the prior literature points the existence of simultaneity among bank risk, bank efficiency and bank capital, still it is a good idea to check the existence of endogenity before proceeding to the analysis of these variables. To empirically justify the simultaneity of bank risk, bank efficiency and bank capital we apply the Hausman test for endogeneity. Here the null hypothesis is that the variables are exogenous. According to Table 6, the results of Hausman test for endogeneity suggest that the exogeneity of bank risk, bank efficiency and bank capital variables in the respective equations can be firmly rejected. 
Table 6: Hausman's test of Endogeneity

\begin{tabular}{|c|c|c|c|}
\hline & Risk Equation & Efficiency Equation & Capital Equation \\
\hline Regressors tested & TCTR, CIR & TCTR, NPLGL & NPLGL, CIR \\
\hline $\begin{array}{c}\text { Hausman test for } \\
\text { endogeneity (p-value) }\end{array}$ & 25.7720 .0000 & 17.6710 .0001 & 12.6300 .0018 \\
\hline
\end{tabular}

\subsection{Impact of Basel's Capital Regulation}

This section reports the impact of Basel capital regulations on the bank risk and bank efficiency along with discussion of these results.

\subsubsection{Impact of Basel's capital regulations on bank risk}

Table 7 shows factors affecting the risks of banks. According to our findings, Total Capital to Total Risk Weighted Assets (TCTR) has negative impact on the credit risks taken by the bank. According to our findings, banks with higher TCTR incline to take lower risks and vice versa. We can conclude that risk-based capital regulations are successful in decreasing bank credit risks in Pakistan. So we are in favor of accepting $\mathrm{H} 1 \mathrm{~B}$ i.e. moral hazard hypothesis, which also advocates a negative association between the two. Here our results are in agreement with Jacques and Nigro (1997), Lee and Hsieh (2013), Haq et al. (2014) etc. Those reporting a negative relationship between two variables cite the presence of deposit insurance for this inverse relationship. However in Pakistan there was no deposit insurance scheme existed during the time period of this study. This indicates that in addition to capital regulations, there might be some other forces or factors that discouraged banks from taking excessive risks. Our results also highlight that impact of bank inefficiency on bank risk is negative and it is significant at $10 \%$. Here our results are pointing towards positive impact of bank efficiency on bank risk. So according to our results the efficient bank takes more risk. One reason can be that cost efficiency allows banks cushion to take on more risk. Thus here we are accepting $\mathrm{H} 2 \mathrm{~A}$ which corresponds to skimping hypothesis in this study by advocating a positive relation between the two. Here we are following the results of Fiordelisi et al. (2011) and Tan and Floros (2013).

Net Loans to Total Asset (NLTA) has negative effect on the risk taken by commercial banks as the coefficient of NLTA is negative and highly significant at $1 \%$. A high NLTA is sign of small liquidity, which may increase funding cost and also increase the credit risk of the bank. In that case, the effect of liquidity ratio may be negative. Here we are following the results of Tan and Floros (2013). Bank size has highly significant negative impact on the bank risk. This is shown by the sign of coefficient and p value of size. It indicates that larger banks have lower risks than smaller ones. One reason 
Table 7: GMM Results of Risk Equation 1997-2015

\begin{tabular}{|c|c|c|}
\hline Variable & Coefficient & Standard Error \\
\hline TCTR & $-0.380^{* * *}$ & 0.141 \\
\hline CIR & $-0.243^{*}$ & 0.130 \\
\hline NLTA & $-0.650^{* * *}$ & 0.102 \\
\hline SIZE & $-0.348^{* * *}$ & 0.101 \\
\hline INF & $0.172^{* * *}$ & 0.056 \\
\hline Chi Sq & $60.81^{* * *}$ \\
\hline No. of observations & 311 \\
\hline No. of banks & 31 \\
\hline No. of instruments & 10 \\
\hline Hansen test (p-value) & \\
\hline \multicolumn{2}{|c|}{0.194} \\
\hline $\begin{array}{c}\text { AR (2) test (p-value) } \\
\text { Difference-in-Hansen test (p-values): GMM } \\
\text { instruments for levels }\end{array}$ & 0.577 \\
\hline **** ** * Significant at the 1\%, 5\%, and 10\% levels \\
\hline
\end{tabular}

might be that their size allows them to diversify their portfolios from risky loans or big banks may not be making risky loans and they might be opting for less risky options e.g. treasury bills etc. Here we are following the results of $\mathrm{Hu}, \mathrm{Li}$, and Chiu (2004), Jacques and Nigro (1997), Aggarwal and Jacques (1998), Altunbas et al. (2007) etc. As far as impact of inflation is concerned, it is positive and highly significant at $1 \%$. One justification can be given that during this time period average inflation was around $8 \%$, so these inflationary pressures played their part in enhancing the level of impaired loans, which increase the credit risks of banks. Here we are following Fofack (2005) results.

In order to quantify the impact of different Basel regulations, we divided our sample into subsamples. Since Basel III was implemented from 2014, so there were not enough annual observations to check the effect of Basel III capital regulations on bank risk. So we divided them into two subsamples i.e. Basel I and Basel II. Table 8 presents the results of determinants of bank credit risk of Pakistani commercial banks for the sub samples Basel I and Basel II.

Table 8 shows that Basel I capital regulation has no impact on the risk taking activities of banks in our investigation, while the Basel II has reduced the risks taken by banks. This is surprising due to the fact that though there is considerable difference between Basel I and Basel II; however capital requirements were same in both Basel I and Basel II. The impact of cost inefficiency has statistically significant negative impact 
Table 8: Comparison of GMM results of Risk Equation

\begin{tabular}{|c|c|c|c|c|}
\hline & \multicolumn{2}{|c|}{ Basel I } & \multicolumn{2}{|c|}{ Basel II } \\
\hline & Coefficient & Standard Error & Coefficient & Standard Error \\
\hline TCTR & -0.100 & 0.160 & $-0.282^{* * *}$ & 0.116 \\
\hline CIR & $-0.541^{* *}$ & 0.276 & 0.468 & 0.062 \\
\hline NLTA & $-0.601^{* * *}$ & 0.073 & $-0.345^{* * *}$ & 0.097 \\
\hline SIZE & -0.065 & 0.114 & $-0.072^{* * *}$ & 0.124 \\
\hline INF & -0.257 & 0.157 & 0.055 & 0.038 \\
\hline Chi Sq. & \multicolumn{2}{|c|}{$439.30^{* * *}$} & \multicolumn{2}{|c|}{$44.48^{* * *}$} \\
\hline No. of observations & \multicolumn{2}{|c|}{148} & \multicolumn{2}{|c|}{135} \\
\hline No. of banks & \multicolumn{2}{|c|}{28} & \multicolumn{2}{|c|}{30} \\
\hline No. of instruments & \multicolumn{2}{|c|}{12} & \multicolumn{2}{|c|}{12} \\
\hline Hansen test (p-value) & \multicolumn{2}{|c|}{0.105} & \multicolumn{2}{|c|}{0.327} \\
\hline AR (2) test (p-value) & \multicolumn{2}{|c|}{0.296} & \multicolumn{2}{|c|}{0.390} \\
\hline $\begin{array}{l}\text { Difference-in-Hansen test } \\
\text { (p-values): GMM instru- } \\
\text { ments for levels }\end{array}$ & \multicolumn{2}{|c|}{0.651} & \multicolumn{2}{|c|}{0.162} \\
\hline
\end{tabular}

on bank risk in Basel I and it has no impact on risk taken by banks in Basel II. Thus we conclude that during Basel I time period, efficiency allowed banks incentive to take more risk, however during Basel II that is not the case. The impact of NLTA on bank risk is same across all the sub samples i.e. negative and remains significant in all sub samples. The same can't be said about the impact of size, though sign of coefficient remains same, however it loses its statistical significance in Basel I and it does affect negatively bank risk in Basel II. The impact of inflation on BR in Basel II is in align with the impact of effect of inflation on Bank risk during the whole time period i.e. 1997-2015. However its impact is not significant in Basel I time period. The results of sub sample II are painting the same story as of main sample. The different impact of inflation on risk taken by banks can be attributed to the fact that during Basel II Pakistan was experiencing high inflation than Basel I.

From the above discussion it is pretty much clear that though overall Basel capital regulations has decreased the risk taken by banks by decreasing non-performing loans, however this reduction is not consistent across all Basel accords, especially Basel I has not the reduced the risks taken by banks. One possible justification can be when Basel I came into play, majority of banks were already maintaining the required capital ratio of $8 \%$. So this compliance to capital regulations did not affect their risk taking. 
During the time period of this study there was couple of important political events in Pakistan. On 12 October 1999 Musharraf's took over as CEO and imposed Martial Law and it ended on 18 August 2008 (Habib, 2012). From that time period to 2015 there is democracy in Pakistan. To assess the impact of capital regulations on the risk taken by the banks in different politic systems, this study has also distributed the sample into sub sample on the basis of different political regimes i.e. from 1999 to 2008 as non-democratic and 2009 to 2015 as democratic regime. Table 9 presents the results of both regimes. By having a look at table 9 it becomes clear that there is not much difference of the impact of capital regulations on the risks taken by the banks in both the style of governments. Basel capital regulations in both the time frames have decreased the risk taken by the banks. Though, banking was one of profitable industry during 1999-2007 and banks provided more loans as well. However, time frame of implementation of the Basel guidelines almost coincides with the time frame of regime switching in Pakistan so there is not much difference of the impact of capital regulations on the risks taken by the banks during non-democratic administration of Pervez Musharraf and democratic governments. The interpretation of the other variables is discussed already in previous and subsequent tables.

Table 8: Comparison of GMM results of Risk Equation

\begin{tabular}{|c|c|c|c|c|}
\hline & \multicolumn{2}{|c|}{ Non-Democratic } & \multicolumn{2}{|c|}{ Democratic } \\
\hline & Coefficient & Standard Error & Coefficient & Standard Error \\
\hline TCTR & $-0.247^{*}$ & 0.144 & $-0.311^{* *}$ & 0.164 \\
\hline CIR & -0.143 & 0.307 & $0.175^{*}$ & 0.096 \\
\hline NLTA & $-0.589^{* * *}$ & 0.105 & $-0.240^{* * *}$ & 0.075 \\
\hline SIZE & -0.132 & 0.135 & $-0.274^{* *}$ & 0.125 \\
\hline INF & $0.158^{* *}$ & 0.061 & 0.008 & 0.049 \\
\hline Chi Sq & \multicolumn{2}{|c|}{$39.85^{* * *}$} & \multicolumn{2}{|c|}{$31.62^{* * *}$} \\
\hline No. of observations & \multicolumn{2}{|c|}{161} & \multicolumn{2}{|c|}{135} \\
\hline No. of banks & \multicolumn{2}{|c|}{30} & \multicolumn{2}{|c|}{29} \\
\hline No. of instruments & \multicolumn{2}{|c|}{12} & \multicolumn{2}{|c|}{12} \\
\hline Hansen test (p-value) & \multicolumn{2}{|c|}{0.240} & \multicolumn{2}{|c|}{0.282} \\
\hline AR (2) test (p-value) & \multicolumn{2}{|c|}{0.312} & \multicolumn{2}{|c|}{0.565} \\
\hline $\begin{array}{l}\text { Difference-in-Hansen test } \\
\text { (p-values): GMM instru- } \\
\text { ments for levels }\end{array}$ & \multicolumn{2}{|c|}{0.521} & \multicolumn{2}{|c|}{0.246} \\
\hline
\end{tabular}




\subsubsection{Impact of Basel's capital regulations on bank efficiency}

With respect to TCTR as determinant of bank efficiency is concerned, the greater is the capital ratio, lower is the efficiency of banks in our sample. Here our results are accepting H3B i.e. shareholders-managers hypothesis. This hypothesis advocates negative impact of capital on efficiency.

Here according to our estimation capital regulations of Basel accords have decreased the efficiency of banks in our sample. One possible reason can come from agency theory. As majority of banks in our sample are listed and private. Due to conflicts of interest between shareholders and managers, managers may minimize their efforts instead of increasing the firm value of company thus in turn decreasing the efficiency of banks. So in order to reduce the moral hazard behavior of managers and monitor their activities, depositor may force banks to increase capital ratios. Thus, there might be negative impact between the two. Here we are in agreement with the results of Berger and Di Patti (2006).

Table 10: GMM of Efficiency Equation

\begin{tabular}{|c|c|c|}
\hline Variable & Coefficient & Standard Error \\
\hline TCTR & $0.194^{*}$ & 0.106 \\
\hline NPLGL & $0.260^{* *}$ & 0.104 \\
\hline NIM & $-0.285^{* * *}$ & 0.075 \\
\hline SIZE & -0.060 & 0.062 \\
\hline INF & $0.118^{* * *}$ & 0.030 \\
\hline Chi Sq & \multicolumn{2}{|c|}{$109.68^{* * *}$} \\
\hline No. of observations & \multicolumn{2}{|c|}{303} \\
\hline No. of banks & \multicolumn{2}{|c|}{31} \\
\hline No. of instruments & \multicolumn{2}{|c|}{10} \\
\hline Hansen test (p-value) & \multicolumn{2}{|c|}{.510} \\
\hline AR (2) test (p-value) & \multicolumn{2}{|c|}{0.353} \\
\hline $\begin{array}{l}\text { Difference-in-Hansen test (p-values): } \\
\text { GMM instruments for levels }\end{array}$ & \multicolumn{2}{|c|}{0.240} \\
\hline
\end{tabular}

Our results also point out that the impact of credit risk taken by the banks on bank efficiency is negative. According to our results efficient banks take less risk. This is intuitively justifiable that banks whose non-performing loans are higher might need to allocate additional resources to monitor those loans. So during this process, cost efficiency decreases. One justification of this negative relationship can be inefficient 
management, as depicted by the low cost efficiency, may not monitor the loans so credit risks of these inefficient banks increases. Or it might be due to unavoidable economic circumstances outside the bank's control that bad loans may arise. The less efficient banks will take more risk to compensate the effect of inefficiency. Thus all this discussion highlights that efficient banks are better at managing their credit risk and hence it leads to lower non-performing loans. This leads us to accept the hypothesis H2B, i.e. bad management or bad luck hypothesis. Here we are in agreement with the results put forward by Altunbas, Liu, Molyneux, and Seth (2000).

Table 10 also shows that net interest margin (NIM) of banks in sample has positive impact on bank efficiency. The banks with high NIM have high cost efficiency and this impact is significant at $1 \%$. This is according to the expectations as high interest income means interest generated is greater than interest expensed. Therefore, less amount interest expenses allow banks to be more cost efficient. Bank size negatively affects bank inefficiency. However, this impact is not significant. So size has no impact on the cost efficiency of banks in our sample. When we focus our attention to impact of inflation on the bank inefficiency, its result depicts that Inflation has negative impact on cost efficiency in our main sample. It is because during inflationary period as was the case in Pakistan during the time period of this research, banks may

Table 11: Comparison of GMM of Efficiency Equation

\begin{tabular}{|c|c|c|c|c|}
\hline & \multicolumn{2}{|c|}{ Basel I } & \multicolumn{2}{|c|}{ Basel II } \\
\hline & Coefficient & Standard Error & Coefficient & Standard Error \\
\hline TCTR & $0.371^{* * *}$ & 0.075 & 0.159 & 0.139 \\
\hline NPLGL & $0.213^{* *}$ & 0.092 & 0.177 & 0.147 \\
\hline NIM & $-0.312^{* * *}$ & 0.081 & $-0.434^{* * *}$ & $0.150^{* * *}$ \\
\hline SIZE & 0.089 & 0.079 & -0.196 & 0.138 \\
\hline INF & 0.038 & 0.120 & 0.057 & 0.075 \\
\hline Chi Sq & \multicolumn{2}{|c|}{$60.33^{* * *}$} & \multicolumn{2}{|c|}{$99.44^{* * *}$} \\
\hline No. of observations & \multicolumn{2}{|c|}{143} & \multicolumn{2}{|c|}{133} \\
\hline No. of banks & \multicolumn{2}{|c|}{25} & \multicolumn{2}{|c|}{30} \\
\hline No. of instruments & \multicolumn{2}{|c|}{10} & \multicolumn{2}{|c|}{10} \\
\hline Hansen test (p-value) & \multicolumn{2}{|c|}{.793} & \multicolumn{2}{|c|}{.359} \\
\hline AR (2) test (p-value) & \multicolumn{2}{|c|}{0.395} & \multicolumn{2}{|c|}{0.405} \\
\hline $\begin{array}{l}\text { Difference-in-Hansen test } \\
\text { (p-values): GMM instru- } \\
\text { ments for levels }\end{array}$ & \multicolumn{2}{|c|}{0.619} & \multicolumn{2}{|c|}{0.318} \\
\hline
\end{tabular}


be spending more to catch up with increasing expenses such as personnel as well as other inputs. So, it might have decreased the efficiency. Table 11 shows the results of factors affecting bank efficiency of Pakistani commercial banks for different subsamples. Here some variables are impacting the cost efficiency in the same way as in the main sample while some variables are behaving in different manner.

There are mix observations found in these results. The results of Basel I regulations are in agreement with result of full sample, however impact of Basel II regulations are insignificant. This is again somewhat unexpected as there is not much difference with respect to capital requirements of Basel I and Basel II. This result again highlights the negative impact of Basel I on bank performance. As far as impact of bank risk on bank efficiency is concerned, the results of Basel I accord are different to Basel II. The impact of risk taken by banks on bank efficiency during Basel II is not significant. One reason could be either banks might not have issued high risk loans during this time period or some other forces have might have played its part in this insignificant impact. The impact of NIM on bank efficiency is positive in all sub samples consistent with the results of sample. The impact of size is different subsamples and same is true about the impact of inflation.

It is concluded from the results presented in Table 10 that Basel capital requirements have lowered the cost efficiency of banks. When we turn our attention to Table 11, Basel I results tell the same story, however Basel II had no impact on the cost efficiency. This again points to the inability of Basel I in increasing the efficiency of banks.

\subsubsection{The capital equation}

The results of having bank capital as dependent variable using GMM are reported in Table 12. The coefficient of bank risk has a positive sign, however this is not significant. As far as impact of bank inefficiency on bank capital is concerned, it has a positive sign and it is highly significant at $1 \%$. So we are advocating a highly significant negative impact of bank efficiency on bank capital. In our sample efficient bank possesses low capital ratios and vice versa. The relation can be justified by the "efficiency-risk hypothesis". This hypothesis argues that high efficiency signals low bankruptcy. As a result banks can afford to lower their capital as they have low default risk due to high efficiency.

The effect of LADSTF on bank capital is positive and statistically significant. A high value of LADSTF indicates high liquidity and this increase in bank liquidity have a positive impact on the capital ratio through its effect on the changes in required rate of return on bank shares. As per expectations, we obtain a positive relationship 
between return on assets (ROAA) and capital, such that banks with higher earnings also tend to operate with high capital. The impact of size on bank capital ratio is positive. Our study reports that big banks have high capital ratio and vice versa. This positive impact can be justified by the franchise value hypothesis. According to this higher earnings lead to greater diversification, so to more investment opportunities and thus lowering the cost of capital provide incentives for large banks to raise more equity capital to avoid taking extraordinary risk. Inflation does not affect capital ratio in our sample.

Table 12: GMM of Capital Equation

\begin{tabular}{|c|c|c|}
\hline Variable & Coefficient & Standard Error \\
\hline NPLGL & 0.021 & 0.085 \\
\hline CIR & $0.337^{* * * *}$ & 0.104 \\
\hline LADSTF & $0.249^{* * *}$ & 0.073 \\
\hline ROAA & $0.332^{* * *}$ & 0.068 \\
\hline SIZE & $-0.140^{* * *}$ & 0.059 \\
\hline INF & 0.033 & .0297 \\
\hline Chi Sq & \multicolumn{2}{|c|}{$36.33^{* * *}$} \\
\hline No. of observations & \multicolumn{2}{|c|}{303} \\
\hline No. of banks & \multicolumn{2}{|c|}{31} \\
\hline No. of instruments & \multicolumn{2}{|c|}{13} \\
\hline Hansen test (p-value) & \multicolumn{2}{|c|}{.341} \\
\hline AR (2) test (p-value) & \multicolumn{2}{|c|}{0.100} \\
\hline $\begin{array}{l}\text { Difference-in-Hansen test (p-values): } \\
\text { GMM instruments for levels }\end{array}$ & \multicolumn{2}{|c|}{0.585} \\
\hline
\end{tabular}

With respect to the effect of different factors on bank capital is concerned, as shown in Table 13 here Basel I is showing different story to that of Basel II in line with previous findings of this study.

\subsubsection{Impact of Moderating Effect of Size}

Table 14 presents the results of more comprehensive analysis of the moderating effect of bank size on the relationship between bank risk taken and bank efficiency. Keppel and Zedeck (1989) suggested that the proposed moderator should be used as independent variable and then as an interaction term. By following Keppel and Zedeck (1989), this study perceives size as moderator by using the interaction term of bank inefficiency and bank size. The significant negative effect of the interaction term on 
Table 13: Comparison of GMM of Capital Equation

\begin{tabular}{|c|c|c|c|c|}
\hline & \multicolumn{2}{|c|}{ Basel I } & \multicolumn{2}{|c|}{ Basel II } \\
\hline & Coefficient & Standard Error & Coefficient & Standard Error \\
\hline NPLGL & $0.134^{* * *}$ & 0.061 & -0.103 & 0.181 \\
\hline CIR & -0.136 & 0.433 & $0.574^{* *}$ & $.264^{* *}$ \\
\hline LADSTF & 0.253 & 0.037 & $0.781^{* * *}$ & $0.132^{* * *}$ \\
\hline ROAA & 0.050 & 0.215 & $0.4726^{* * *}$ & $0.149^{* * *}$ \\
\hline SIZE & $-0.218^{* * *}$ & $0.062^{* * *}$ & $-0.367^{* * *}$ & $0.119^{* * *}$ \\
\hline INF & 0.161 & $0.080^{* *}$ & 0.044 & 0.057 \\
\hline Chi Sq & \multicolumn{2}{|c|}{$71.06^{* * *}$} & \multicolumn{2}{|c|}{$92.54^{* * *}$} \\
\hline No. of observations & \multicolumn{2}{|c|}{143} & \multicolumn{2}{|c|}{133} \\
\hline No. of banks & \multicolumn{2}{|c|}{25} & \multicolumn{2}{|c|}{30} \\
\hline No. of instruments & \multicolumn{2}{|c|}{11} & \multicolumn{2}{|c|}{11} \\
\hline Hansen test (p-value) & \multicolumn{2}{|c|}{0.469} & \multicolumn{2}{|c|}{0.451} \\
\hline AR (2) test (p-value) & \multicolumn{2}{|c|}{0.514} & \multicolumn{2}{|c|}{0.508} \\
\hline $\begin{array}{l}\text { Difference-in-Hansen test } \\
\text { (p-values): GMM instru- } \\
\text { ments for levels }\end{array}$ & \multicolumn{2}{|c|}{0.401} & \multicolumn{2}{|c|}{0.131} \\
\hline
\end{tabular}

***, ${ }^{* *},{ }^{*}$ Significant at the $1 \%, 5 \%$, and $10 \%$ levels

the bank credit risk advocates that the of bank size is playing its role as moderator in reducing the risks taken by the banks in this study. One justification can be that the economies of scale enjoyed by the large Pakistani banks enable them to benefit from reduced risk. Here we are in agreement with Biekpe (2011) findings.

Table 12: GMM of Capital Equation

\begin{tabular}{|c|c|c|}
\hline Variable & Coefficient & Standard Error \\
\hline TCTR & 2.816 & 1.891 \\
\hline CIR & -0.065 & 0.172 \\
\hline NLTA & $-0.639^{* * *}$ & 0.097 \\
\hline SIZE & 0.372 & 0.423 \\
\hline INF & $0.164^{* * *}$ & 0.056 \\
\hline CIR*SIZE & $-17.804^{*}$ & 10.425 \\
\hline Chi Sq & $85.44^{* * *}$ \\
\hline No. of observations & \multicolumn{2}{|c|}{311} \\
\hline No. of banks & \multicolumn{2}{|c|}{} \\
\hline
\end{tabular}




\begin{tabular}{|c|c|}
\hline No. of instruments & 11 \\
\hline Hansen test (p-value) & 0.211 \\
\hline AR (2) test (p-value) & 0.576 \\
\hline $\begin{array}{c}\text { Difference-in-Hansen test (p-values): } \\
\text { GMM instruments for levels }\end{array}$ & 0.216 \\
\hline$* * * * *,{ }^{*}$ Significant at the $1 \%, 5 \%$, and 10\% levels \\
\hline
\end{tabular}

\section{Conclusion}

The purpose of this paper is to analyze the relationship between capital, risk and efficiency of Pakistani commercial banks from 1997 to 2015. We used Generalized Method of Moments (GMM) model in which cost efficiency, credit risk and Capital adequacy ratio are used as dependent variables. According to our results, Basel capital regulation reduced the risk taken by banks during 1997-2015. As far as impact of capital regulation on the cost efficiency of banks is concerned, it had an opposite effect on the cost efficiency of banks. Banks in our sample had seen their efficiency decreased by virtue of capital regulations. Our results also point out that Basel II was more successful in decreasing the risk taken by banks as compared to Basel I.

\section{References}

Aggarwal, R., \& Jacques, K. T. (1998). Assessing the impact of prompt corrective action on bank capital and risk. Federal Reserve Bank of New York Economic Policy Review, 4(3), 23-32.

Altunbas, Y., Carbo, S., Gardener, E. P., \& Molyneux, P. (2007). Examining the relationships between capital, risk and efficiency in European banking. European Financial Management, 13(1), 49-70.

Altunbas, Y., Liu, M. H., Molyneux, P., \& Seth, R. (2000). Efficiency and risk in Japanese banking. Journal of Banking E्S Finance, 24(10), 1605-1628.

Barth, J. R., Caprio, G., \& Levine, R. (2004). Bank regulation and supervision: What works best? Journal of Financial Intermediation, 13(2), 205-248.

Berger, A. N., \& De Young, R. (1997). Problem loans and cost efficiency in commercial banks. Journal of Banking $\mathcal{E}$ Finance, 21(6), 849-870.

Berger, A. N., \& Di Patti, E. B. (2006). Capital structure and firm performance: A new approach to testing agency theory and an application to the banking industry. Journal of Banking $\mathcal{E}$ Finance, 30(4), 1065-1102.

Biekpe, N. (2011). The competitiveness of commercial banks in Ghana. African Development Review, 23(1), 75-87.

Carbó, S., Humphrey, D., Maudos, J., \& Molyneux, P. (2009). Cross-country comparisons of competition and pricing power in European banking. Journal of International Money and Finance, 28(1), 115-134. 
Das, A., \& Ghosh, S. (2004). Risk, capital and operating efficiency: Evidence from Indian public sector banks. Indian Journal of Economics and Business, 1(3), 147-164

de Guevara, J. F., Maudos, J., \& Pérez, F. (2007). Integration and competition in the European financial markets. Journal of International Money and Finance, 26(1), 26-45.

Diamond, D. W. (1984). Financial intermediation and delegated monitoring. The Review of Economic Studies, 51(3), 393-414.

Fama, E. F. (1980). Banking in the Theory of Finance. Journal of Monetary Economics, 6(1), 39-57.

Fiordelisi, F., Marques-Ibanez, D., \& Molyneux, P. (2011). Efficiency and risk in European Banking. Journal of Banking $\mathcal{E}$ Finance, 35(5), 1315-1326.

Fofack, H. (2005). Nonperforming loans in Sub-Saharan Africa: Causal analysis and macroeconomic implications. World Bank Policy Research Working Paper, 3769.

Gujarati, D. N. (2009). Basic econometrics. (4th ed.). London: McGraw-Hill.

Habib, M. U. (2012). Musharraf Era, Martial Law and major reforms. Retrived October 02, 2016, from http://www.hamariweb.com/articles/article.aspx?id=21991

Haq, M., Faff, R., Seth, R., \& Mohanty, S. (2014). Disciplinary Tools and Bank Risk Exposure. Pacific-Basin Finance Journal, 26(1), 37-64.

Hu, J. L., Li, Y., \& Chiu, Y. H. (2004). Ownership and nonperforming loans: Evidence from Taiwan's banks. The Developing Economies, 42(3), 405-420.

Jacques, K., \& Nigro, P. (1997). Risk-based capital, portfolio risk, and bank capital: A simultaneous equations approach. Journal of Economics and Business, 49(6), 533-547.

Jensen, M. C., \& Meckling, W. H. (1976). Theory of the firm: Managerial behavior, agency costs and ownership structure. Journal of financial economics, 3(4), 305-360.

Keppel, G., \& Zedeck, S. (1989). Data analysis for research designs: Analysis-of-variance and multiple regression/ correlation approaches ( $1^{\text {st }} \mathrm{ed}$.). NY: W.H. Freeman.

Kim, D., \& Santomero, A. M. (1988). Risk in banking and capital regulation. The Journal of Finance, 43(5), 1219-1233.

Kwan, S., \& Eisenbeis, R. A. (1997). Bank risk, capitalization, and operating efficiency. Journal of Financial Services Research, 12(2-3), 117-131.

Laeven, L., \& Valencia, F. (2013). Systemic banking crises database. IMF Economic Review, 61(2), 225-270.

Lee, C. C., \& Hsieh, M.F. (2013). The impact of bank capital on profitability and risk in Asian Banking. Journal of International Money and Finance, 32(1), 251-281.

Levine, R. (1997). Financial development and economic growth: Views and agenda. Journal of Economic 
Literature, 35(2), 688-726.

Levine, R., \& Zervos, S. (1998). Stock markets, banks, and economic growth. American Economic Review, $88(3), 537-558$.

Miah, M. D., \& Sharmeen, K. (2015). Relationship between capital, risk and efficiency: A comparative study between Islamic and conventional banks of Bangladesh. International Journal of Islamic and Middle Eastern Finance and Management, 8(2), 203-221.

Mourlon-Druol, E. (2015). Trust is good, control is better: The 1974 Herstatt Bank Crisis and its implications for international regulatory reform. Business History, 57(2), 311-334.

Pasiouras, F., Tanna, S., \& Zopounidis, C. (2009). The impact of banking regulations on banks' cost and profit efficiency: Cross-country evidence. International Review of Financial Analysis, 18(5), 294-302.

Pettway, R. H. (1976). Market tests of capital adequacy of large commercial banks. The Journal of Finance, 31(3), 865-875.

Repullo, R., \& Suarez, J. (2008). The procyclical effects of Basel II. Center for Monetary and Financial Studies, Working Paper, 0809.

Roodman, D. (2006). How to do xtabond2: An introduction to difference and system GMM in Stata. Stata Journal, 9(1), 86-136.

Roodman, D. (2009). A note on the theme of too many instruments. Oxford Bulletin of Economics and statistics, 71(1), 135-158.

Santos, J. A. (2001). Bank capital regulation in contemporary banking theory: A review of the literature. Financial Markets, Institutions $\mathcal{E}$ Instruments, 10(2), 41-84.

Scholes, M., Benston, G. J., \& Smith, C. W. (1976). A transactions cost approach to the theory of financial intermediation. The Journal of Finance, 31(2), 215-231.

Shrieves, R. E., \& Dahl, D. (1992). The Relationship between risk and capital in commercial banks. Journal of Banking $\mathcal{E}$ Finance, 16(2), 439-457.

Stock, J. H., \& Watson, M. W. (2011). Introduction to Econometrics. (3 ${ }^{\text {rd }}$ ed.). Boston, MA: Addison-Wesley

Tan, Y., \& Floros, C. (2013). Risk, capital and efficiency in Chinese banking. Journal of International Financial Markets, Institutions and Money, 26(4), 378-393. 
